\title{
PELATIHAN KETERAMPILAN PEMANFAATAN SISTEM KONVERSI ENERGI ANGIN SEBAGAI PEMBANGKIT LISTRIK ALTERNATIF MELALUI TEKNOLOGI TURBIN ANGIN DALAM UPAYA MENINGKATKAN PRODUKTIVITAS PETERNAK ITIK DI DESA MUARA HALAYUNG
}

\author{
Mujiburrahman, Muhammad Marsudi, Yassyir Maulana, dan Saifullah Arief \\ Fakultas Teknik, Universitas Islam Kalimantan \\ E-mail : mujiburrahman.4646@gmail.com
}

\begin{abstract}
ABSTRAK
Selama ini permasalahan yang di hadapi peternak itik hanya mengandalkan suplai listrik dari PLN dan Genset untuk penerangan yang di rasa mahal. Berdasarkan hasil survey pemetaan potensi energi angin di desa muara halayung rata-rata kecepatan angin yang di hasilkan berkisar antara 1 sampai dengan $6 \mathrm{~m} / \mathrm{s}$ yang di rasa sangat potensial apabila di manfaatkan melalui teknologi turbin angin. Tetapi mungkin yang menjadi persoalan lain pengetahuan maupun pemahaman Masyarakat Desa Muara Halayung tentang sistem pemanfaatan energi angin masih sangat minim. Metode pelaksanaan kegiatan pengapdian kepada masyarakat ini di lakukan secara langsung memberikan edukasi pemahaman pengetahuan sistem pemanfataan energi angin kepada para Peternak itik di Desa Muara Halayung dengan melakukan sosialisasi pemaparan materi, memberikan pelatihan pembuatan teknologi pengkonversian turbin angin, dan cara pengaplikasian teknologi turbin angin sebagai energi alternatif pembangkit listrik yang mandiri. Berdasarkan hasil sosialisasi dan edukasi kepada masyarakat dengan adanya sosialisasi ini masyarakat muara halayung lebih memahami pentingnya sumberdaya angin yang di manfaatakan sebagai energi listrik, dengan adanya PKM yang di adakan di desa muara halayung sangat mengedukasi membuat masyarakat khususnya peternak Itik memiliki pengetahuan sistem konversi turbin angin. Selanjutnya hasil pelatihan menunjukkan bahwa masyarakat desa muara halayung khususnya para Peternak itik, tidak hanya memiliki pengetahuan tetapi juga keterampilan membuat sistem konversi energi listrik. Sedangkan hasil pelatihan pengaplikasian turbin, masyarakat desa muara halayung khususnya peternak Itik mampu memahami secara prinsip, baik itu secara mekanikal maupun elektrikal bagaimana teknologi pendayagunaan energi angin, karena mereka memahami prinsip kerja alat dan sistem konversi energi angin.
\end{abstract}

Kata Kunci : Keterampilan, Turbin Angin, Energi Listrik

\section{PENDAHULUAN}

\section{Analisis Situasi}

Desa muara halayung merupakan salah satu desa yang terletak di kecamatan beruntung baru kabupaten banjar. Kondisi geografis yang di miliki muara halayung sangat berbeda dengan desa lain yang ada di kecamatan beruntung baru, Sebagian besar wilayah muara halayung terdiri lahan persawahan, sehingga mayoritas masyaratnya sangat bergantung pada 
sektor pertanian, perikanan, dan peternakan.

Khususnya bidang peternakan yaitu para Peternak itik di rasa belum di tunjang dengan listrik yang optimal dari aspek ekonomi, Selama ini Peternak itik hanya mengandalkan suplai listrik dari PLN untuk penerangan yang di rasa mahal. Jika ini di biarkan hanya terfokus pada tiga sektor tersebut tanpa melihat potensi lain yang jauh lebih menjanjikan khususnya pemberdayaan energi angin yang berpotensi menghasilkan energi listrik melalui teknologi turbin angin. Sedangkan Para Peternak Itik kebanyakan bertempat di tengah persawahan yang lumayan jauh dari pemukiman penduduk dengan alasan agar tidak mencemari lingkungan yang dapat mengganggu masyarakat sekitar.

Berdasarkan hasil survey pemetaan potensi energi angin di desa muara halayung rata-rata kecepatan angin yang di hasilkan berkisar antara 1 sampai dengan $6 \mathrm{~m} / \mathrm{s}$ yang di rasa sangat potensial apabila di manfaatkan melalui teknologi turbin angin. Tetapi mungkin yang menjadi persoalan lain pengetahuan maupun pemahaman Masyarakat Desa Muara Halayung tentang sistem pemanfaatan energi angin masih sangat minim.

Oleh sebab itu melalui program Pengapdian Kepada Masyarakat (PKM) dapat memberikan kontribusi yang nyata bagi masyarakat Desa Muara Halayung dalam pengaplikasian ilmu pengetahuan yang bersumber dari potensi alam, seperti sistem pengkonversian, membuat dan mengaplikasikan turbin angin sehingga program Pengapdian Kepada Masyarakat (PKM) dapat menyentuh langsung dengan masyarakat serta membantu Peternak itik mengurangi biaya operasional seperti pakan dan biaya listrik yang tinggi.

\section{Permasalahan Mitra}

1. Para Peternak Itik tidak memiliki pengetahuan sistem konversi turbin angin.

2. Para Peternak Itik tidak memiliki keterampilan cara pembuatan turbin angin.

3. Para Peternak Itik tidak memiliki pengetahuan pengaplikasian turbin angin.

\section{Solusi Permasalahan Mitra}

Berdasarkan paparan analisis situasi yang mendasari bahwa masyarakat Desa Muara Halayung tidak memiliki pengetahuan pengaplikasian 
energi terbarukan khususnya sistem pengkonversian sumber daya energi angin dan mengaplikasikan turbin angin, karena energi angin memiliki potensi yang sangat menjanjikan karena tidak terorientasi pada cuaca sehingga sangat cocok sebagai pembangkit listrik skala kecil untuk penerangan tambak itik pada malam hari, sehingga mampu mengurangi biaya operasional bagi Peternak itik dan ketergantungan menggunakan jaringan listrik PLN maupun genset sebagai sumber tenaga listrik. Sehingga solusi yang perlu di lakukan untuk membantu para Peternak itik dalam mengurangi ketergantungan suplai aliran listrik sebagai berikut :

1. Memberikan edukasi pengetahuan sistem pengkonversian pemanfaatan energi angin.

2. Memberikan pelatihan keterampilan membuat turbin angin sehingga masyarakat desa muara halayung mampu membuat turbin angin sebagai menghasil energi listrik.

3. Memberikan pelatihan pengetahuan pengaplikasian turbin angin sehingga masyarakat desa muara halayung mampu menghasil energi listrik secara mandiri.

\section{Target Luaran}

1. Para Peternak itik memahami sistem pengkonversian energi angin sebagai pembangkit listrik.

2. Para Peternak itik mampu pembuatan sistem pengkonversian turbin angin sebagai pembangkit listrik.

3. Para Peternak itik mampu mengaplikasikan sistem pengkonversian turbin angin sebagai pembangkit listrik.

4. Di terbitkan pada jurnal pengabdian kepada masyarakat.

\section{KHALAYAK SASARAN}

Khalayak sasaran pada kegiatan pengabdian ini adalah pelaku usaha Peternak itik di Desa Muara Halayung dalam mengurangi ketergantungan persoalan energi listrik seperti jarak, dan biaya operasional yang tinggi.

\section{METODE PELAKSANAAN KEGIATAN \\ Metode Pelaksanaan Kegiatan}

Metode pelaksanaan kegiatan pengapdian kepada masyarakat ini di lakukan secara langsung memberikan edukasi pemahaman pengetahuan sistem pemanfataan energi angin kepada para Peternak itik di Desa Muara Halayung dengan melakukan sosialisasi 
pemaparan materi, memberikan pelatihan pembuatan teknologi pengkonversian turbin angin, dan cara pengaplikasian teknologi turbin angin sebagai energi alternatif pembangkit listrik yang mandiri.

Kegiatan pengabdian kepada masyarakat di diarahkan pada masyarakat pemilik keramba budidaya itik yang berlokasi di Desa Muara Halayung di laksanakan pada bulan Januari 2019 s/d Februari 2020.

\section{HASIL PELAKSANAAN}

\section{KEGIATAN}

Bardasarkan hasil melaksanakan pengabdian kepada masyarakat yang di lakukan di desa muara halayung, selama sesuai dengan program kegiatan ada beberapa kegiatan yang telah dilaksanakan antara lain :

\section{Hasil Survey Lokasi}

Berdasarkan hasil survey lokasi dan melakukan pengukuran potensi angin pada tanggal 16 Desember 2019 di beberapa peternakan itik yang bertempat di desa muara halayung, kecamatan beruntung baru kabupaten banjar, berkisar antara 1 sampai $6 \mathrm{~m} / \mathrm{s}$ sebagai dasar pengembangan pembangkit listrik skala kecil mandiri yang di aplikasikan pada kandang Itik.
Kegiatan yang di lakukan seperti pada gambar 1.

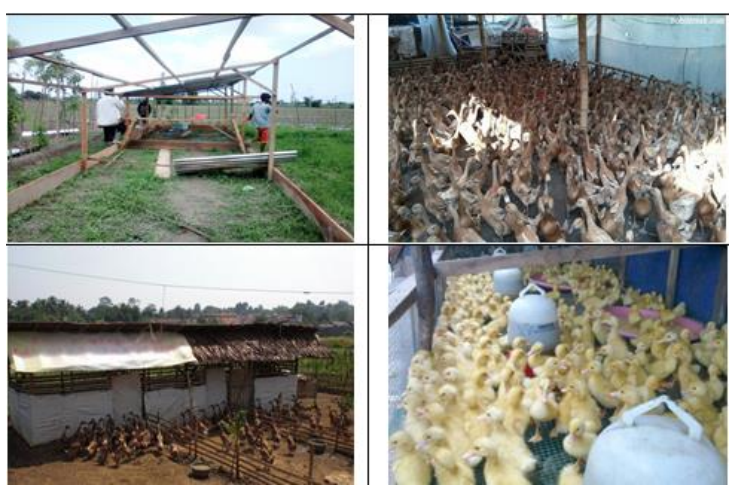

Gambar 1. Lokasi beternakan Itik

\section{Hasil Sosialisai}

Berdasarkan hasil sosialisasi dan memberi edukasi tentang pemanfaatan sumberdaya energi angin sebagai pembangkit listrik skala kecil yang di aplikasikan pada kandang Itik sebagai sumber listrik alternatif dan mandiri. Masyarakat yang hadir khususnya peternak Itik sangat antusias dengan apa yang kami paparkan, karena selama ini mereka bergantung pada suplai listrik pln dan genset di mana memerlukan biaya yang lumayan mahal. Sumber energi yang mereka cita-citakan selama ini terjawab dengan adanya sosialisasi dan edukasi yang kami berikan kepada mereka, bahkan beberapa warga banyak yang tidak sabar untuk melihat secara langsung bagaimana teknologi yang kami tawarkan memanfaatkan sumberdaya energi angin menjadi energi listrik. Kegiatan sosialisai yang 
kami lakukan seperti terlihat pada gambar 2. berikut.

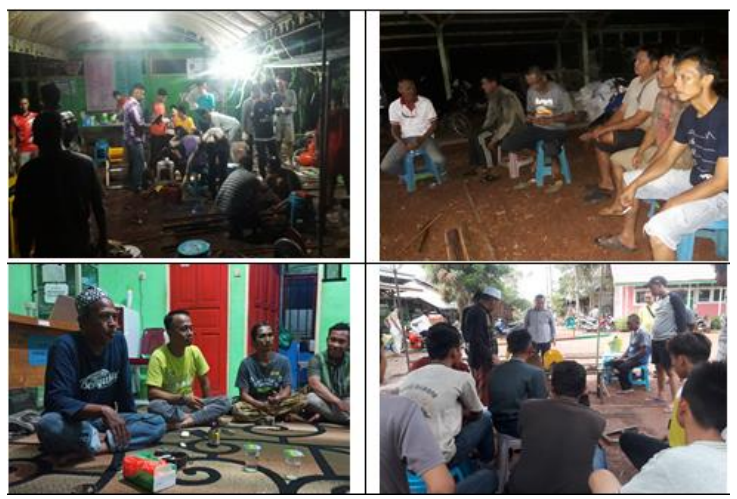

Gambar 2. Memberi sosialisasi pemanfaatan energi angin

\section{Hasil Pelatihan Pembuatan Turbin}

Tingginya keinginan warga desa muara halayung untuk mempelajari cara membuat teknologi memanfaatan sumber daya energi angin, hal itu di tunjukkan banyaknya warga yang datang menunggu untuk mengikuti pelatihan dari kalangan muda sampai orang tua. Selanjutnya kamipun memberi pelatihan kepada warga khususnya peternak Itik bagaimana cara pembuatan turbin angin, baik dari segi dimensi yang sesuai dengan potensi sumber daya angin yang ada di peternakan Itik, selanjutnya memberi pelatihan cara membuat geometri atau bentuk sudu, sistem transmisi ke generator untuk menghasilkan listrik. serta bahan apa yang di gunakan di mana pada pelatihan ini komponen turbin berbahan dasar kayu karena sumberdayanya melimpah, mudah di bentuk, dan biaya manufaktur membuat turbin sangat murah. Kegiatan pelatihan dapat dilihat seperti pada gambar 3 . berikut.

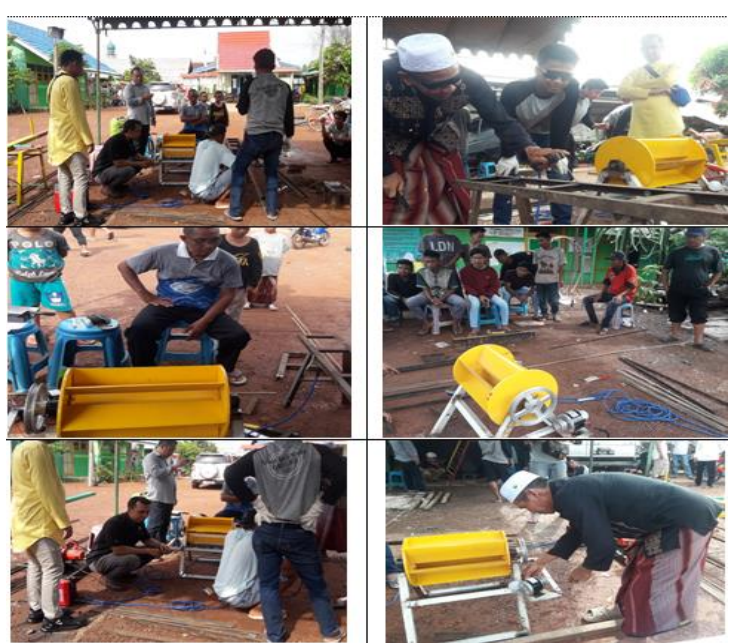

Gambar 3. Memberi pelatihan pembuatan turbin angin

\section{Hasil Pelatihan Perakitan \\ Pengaplikasian Turbin}

Hasil pelatihan kepada warga desa muara halayung sistem kerja turbin angin sebagai pembangkit listrik skala kecil yang di aplikasikan pada kandang Itik. Memberi pelatihan bagaimana cara perakitan komponen turbin, merakit frame sebagai dudukan bantalan turbin, menghubungkan turbin ke generator listrik, selanjutnya agar energi listrik dapat di simpan harus menggunakan inverter selanjutnya ke baterai untuk menyimpan energi listrik yang di hasilkan. Dari hasil pelatihan perakitan yang di lakukan membuat warga 
semakin memahami dan mengerti, sehingga banyak warga terdorong untuk belajar cara pengaplikasian sistem pemanfaatan sumber daya energi angin yang di hasilkan oleh generator listrik, menghubungkan turbin kegenerator listrik di mana generator yang di gunakan pada pelatihan ini, dan instalasi turbin angin sebagai mesin konversi energi memanfaatkan sumber daya potensi angin menjadi energi listrik, baik dari segi bentuk, dimensi, material bahan yang di gunakan, dan prinsip kerja sistem pengkonversian turbin angin sebagai pembangkit listrik skala kecil yang di aplikasikan pada kandang Itik.

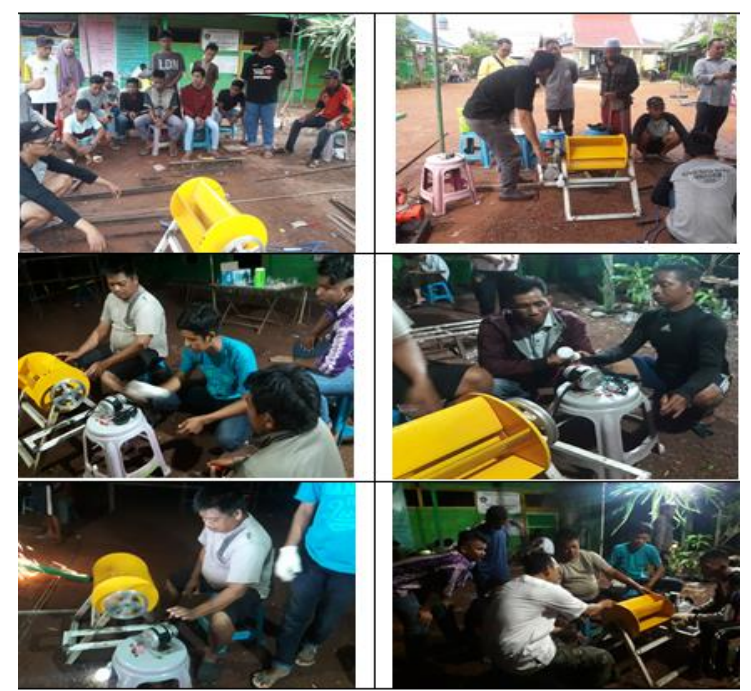

Gambar 4. Memberi pelatihan pengaplikasian instalasi turbin angin

\section{KESIMPULAN}

Dari hasil kegiatan dalam pengapdian kepada masyarakat selama tiga hari yaitu dari tanggal 24 januari sampai dengan 26 januari 2020 dapat ditarik kesimpulan hasil capaian pengabdian kepada masyarakat yang di lakukan di desa muara halayung yaitu sebagai berikut :

1. Berdasarkan hasil sosialisasi dan edukasi kepada masyarakat dengan adanya sosialisasi ini masyarakat muara halayung lebih memahami pentingnya sumberdaya angin yang di manfaatakan sebagai energi listrik, selama ini menurut mereka pemahaman tentang konsep dan gagasan yang berorientasi pada pemanfaatan sumberdaya energi yang ramah ligkungan sangat minim, dengan adanya PKM yang di adakan di desa muara halayung sangat mengedukasi membuat masyarakat khususnya peternak Itik memiliki pengetahuan sistem konversi turbin angin.

2. Berdasarkan hasil pelatihan menunjukkan bahwa masyarakat desa muara halayung khususnya para Peternak itik, tidak hanya memiliki pengetahuan tetapi juga keterampilan hal ini di buktikan dengan antusiasme masyarakat dalam pelatihan pembuatan turbin, masyarak mulai menyadari manfaat 
dan dampak yang mereka peroleh apabila mereka mampu membuat sistem konversi energi listrik yang hanya di aplikasikan di atas atap kandang peternakan Itik, tanpa tergantung dengan alran listrik PLN. Karena sekarang mereka memiliki keterampilan cara pembuatan teknologi turbin angin.

3. Berdasarkan hasil pelatihan pengaplikasian turbin, masyarakat desa muara halayung khususnya peternak Itik mampu memahami secara prinsip, baik itu secara mekanikal maupun elektrikal bagaimana teknologi pendayagunaan energi angin, karena mereka memahami prinsip kerja alat dan sistem konversi energi angin.

\section{DAFTAR PUSTAKA}

Mujiburrahman, Heri Irawan 2018. Analisis Pengaruh Sudu Terhadap Unjuk Kerja Turbin Angin Atap Rumah Pada Kecepatan Angin Rendah Menggunakan Simulasi Cfd.

Eka Maulana, Mujiburrahman, Iskendar, 2016. Meneliti Pengaruh Sudu Terhadap Unjuk Kerja Turbin Angin Atap Rumah Pada Putaran Rendah.

Lukas deisadze, dkk 2013. Vertical Axis Wind Turbine Evaluation and Design.

Andry kusbiantoro, dkk 2013. Pengaruh Lengkung Sudu Terhadap Unjuk Kerja Turbin Angin Poros Vertikal Savonius.

Hendra A. 2012, Pengaruh Jumlah Sudu Terhadap Unjuk KerjaTurbin Angin Savonius.Universitas Brawijaya.

Raymond E. Paggi, 2010. Paten Application Ser. No. 61/105,096, filed Nov.24, 2008, Entidled Roof Ridge Wind Turbine.

Hendra A. 2012, Pengaruh Jumlah Sudu Terhadap Unjuk KerjaTurbin Angin Savonius.Universitas Brawijaya. 